\begin{tabular}{|l|l|}
\hline Asian Journal of Pharmaceutical Research \\
and Development
\end{tabular}

Open $\odot$ Access

Available Online at www.ajprd.com

Research Article

\title{
CRITICAL REVIEW OF MEDA DHATU AND OBESITY IN REFERENCE TO AYURVEDIC LITERATURE
}

\author{
Alok Kumar Asthana ${ }^{1}$, Monika Asthana ${ }^{2}$, Pooja Sabharwal ${ }^{3}$, Rahul Anand ${ }^{*}$ \\ 1. PG Dept of Kriya Sharir, Ch. Brahm Prakash Ayurveda Charak Sansthan, New Delhi, India. \\ 2. PG Dept of Kayachikitsa, State Ayurvedic College, Lucknow, Uttar Pradesh, India. \\ 3. PG Dept of Rachana Sharir, Ch. Brahm Prakash Ayurveda Charak Sansthan, New Delhi, India. \\ 4. *PG Dept of Kriya Sharir, Ch. Brahm Prakash Ayurveda Charak Sansthan, New Delhi, India.
}

\begin{abstract}
Obesity is one of the santarapanajanya vyadhi, originated as a result of deteriorated life style which includes sedentary daily routine and junk food habits. It occurs when the consumption of calories becomes more than its expenditure. It serves as an etiological factor for many diseases. It has reached to the epidemic proportion, affecting majority of the urban population. Obesity can be estimated by various scales among which Body Mass Index (BMI) and skin fold measurements are most common. Obesity is indirectly proportional to Basal Metabolic Rate (BMR). BMR is the amount of energy required to do the involuntary work of the body which is around 47 calories per hour per square meter of body surface in males and 37 in females, but may vary with temperature as a rise in $10 \mathrm{~F}$ of body temperature may lead to an average increase of $7 \%$ of $\mathrm{BMR}^{1}$. Prior to the management of this disorder, it is obligatory to reach to its roots. Ancient scholars tried to elaborate the causes, pathology, types, complications and management of obesity in their own way, and this description is scattered here and there. The present article will try to assemble these references, and find out a common conclusion.
\end{abstract}

KEY WORDS: Sthaulya, meda dhatu, medodhara kala, vasa, mansagni, medo-agni, BMI, BMR

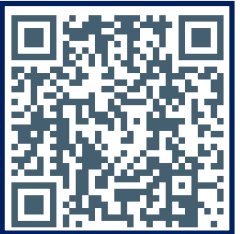

Cite this article as:

Asthana Alok Kumar , Asthana Monika, Sabharwal Pooja , Anand Rahul * Critical Review Of Meda Dhatu And Obesity In Reference To Ayurvedic Literature, Asian Journal of Pharmaceutical research and Development. 2018; 6 (5):26-31 DOI: http://dx.doi.org/10.22270/ajprd.v6i5.417

*Address for Correspondence:

Rahul Anand, PG Dept of Kriya Sharir, Ch. Brahm Prakash Ayurveda Charak Sansthan, New Delhi, India

\section{INTRODUCTION}

$\mathrm{M}$ odernization of technology has no doubt decreased the load of physical work from the people's shoulders, but as a complication, it has lead to the generation of lifestyle disorders. One such disorder, whose incidence is most common in today's era is obesity, which is not only a threatening ailment in itself, but also the cause of origin of other disorders like diabetes, hypertension, etc. Obesity is a medical condition in which excess body fat accumulates to the extent that it may have an adverse effect on health. Incidence of obesity has increased three times since 1975. In 2016, more than 1.9 billion adults, 18 years and older, were overweight. Of these, over 650 million were obese ${ }^{2}$. In a battle against obesity, it's a must to be familiar with this enemy. Considering this issue, the ancient scholars described obesity in the form of sthaulya, in various samhitas. Sthaulya is basically the consequence of dushti of medo dhatu, as is explained by Acharya Bhel in $11^{\text {th }}$ chapter of sutrasthana, "Samashanaparighaniya adhyaya", where he stated that obesity, along with other complications like foul odour from body, excess perspiration, excess thirst, excess sleep and twenty types of prameha are all complications of meda dhatu dushti ${ }^{3}$.

\section{OBESITY IN AYURVEDA}

\section{Origin of meda dhatu}

Besides other norms, definition of swastha also refers to the moderate quantity of the seven dhatus of the body and disorders may develop if there occurs a variation in it. In 
this context, the excess accumulation of meda dhatu (whose normal praman mentioned is 2 anjali by $\mathrm{Charak}^{4}$ ) results in obesity. Although obesity is mentioned in most of the places by Charak, but its $21^{\text {st }}$ chapter, Ashtonindatiya adhyaya is quite important regarding the explanations of this illness. To understand obesity, the knowledge of origin of meda dhatu is mandatory. According to Acharya Charak, meda dhatu is originated from mansa dhatu. ${ }^{5}$ According to modern science, meda is present in fat cell of diameter of around 1/400 to $1 / 500$ inches. It consists of fat in it which is present in liquid state due to the body temperature but in concentrated state when the person dies. Meda is formed from the sneha portion of the ingested food, carbohydrates and the nitrogen deficient proteins.

\section{Medodhara Kala}

Ayurveda gives the concept of Kala. Just as pith (heart wood) is seen when the wood (stem of a tree) is split/cut, similarly when the dhatus such as mamsa (muscles) are cut, kala becomes visible. These are differentiated as snayu praticchana (covered/formed from ligaments), jarayu santata (expansion of/continuation of foetal covering) and slesmavestita (coated with kapha). In present day, kala may be identified as 'membranes'. Acharya Sushruta says that the third kala is medodhara kala ${ }^{6}$.

\section{Location of meda}

Other than few places like testicles and eye lids, medaodhara kala is found almost everywhere in the body beneath the layers of skin and above the mansadhara kala, and meda resides in it. Meda is specially deposited in vapavahan (may be related to omentum) of belly. It is also deposited superficial fascia, hridayadhara (pericardium) and antradhara (mesentery). Meda is deposited in sufficient amount around the kidneys. It is deposited around the eyeballs and around the large blood vessels to protect them from shocks. Meda deposited in pelvic region makes sitting comfortable.

\section{Sarakta Meda}

Meda is found in small bones, whereas majja in large bones. Meda found in rest of the bones is sarakta meda, as is mentioned by Sushruta in Garbhavyakarana sharira in sharir sthana? ${ }^{7}$ The majja may be resembled with yellow marrow, since it is present in all the large bones and similarly sarakta meda may be correlated to red marrow. Some scholars say that the sarakta meda cannot be placed in category of majja dhatu, because unlike majja dhatu, sarakta meda cannot be taken through oral administration, because in meda, the sneha portion is not in isolated form, but is chemically bonded to other compounds and its chemical structure gets altered when it gets digested in the gastro intestinal tract.

\section{Etiology of Obesity}

Indicating the importance of this disorder, a separate chapter "Medorogadhikar" is mentioned in Yogaratnakara. Describing the etiology, he says that due to lack of exercise, sleeping during day time and intake of kapha increasing diet the sweet juices of the (ingested) food are converted into sneha (fatty acids) which leads to increase in fat. ${ }^{8} \mathrm{He}$ also explains its pathogenesis and quotes that since the increased meda blocks the channels, so the other dhatus are not properly nourished, as a result fat is further increased and the person becomes incapable of performing the physical activities. ${ }^{9}$

\section{Role of hormones in metabolism of meda}

The digestion of meda is mainly regulated by mans-agni and medo-agni. Mans-agni digests mansa to form meda dhatu and medo-agni digests meda to form asthi dhatu. These agni may be related to the hormones secreted by various endocrine organs of the body. Insulin secreted by pancreas digests carbohydrates and also maintains the level of meda at optimum level. Thyroid gland regulates these metabolisms and regulates the amount of deposition of meda in the body. Pituitary too has an impact in controlling the metabolism, and hence the deposition of meda in body. Abnormal secretions of these hormones may result in formation of lumps, known as medo-arbud (lipomas).

\section{Effect of meda vriddhi on heart}

Normally meda is present over medodhara kala (pericardium) which acts as shock absorber. But due to extra meda producing reasons, much of the meda may get deposited over heart. Due to this, the development of heart retards and its efficiency decreases, and it is unable to fulfill the demands of oxygen, nutrients, hormones etc of various organs and remove carbon dioxide and other metabolic wastes from their places. The increase in amount of $\mathrm{CO}_{2}$ in blood stimulates the respiratory centre of the brain. This makes the respiration rapid and shallow and the person feels breathlessness even on slight exertion.

\section{Function}

The significance of meda dhatu can better be understood only after analyzing its widespread purposes all over the body. The function of meda dhatu is to oliate the body, produce sweat, make the body strong and nourish the bones, according to Acharya Sushruta as mentioned in chapter 15, Doshadhatumalakshayavridhhivigyaniya adhyaya of sutrasthana ${ }^{10}$. Meda, in combination with other constituents, is an important part of the cell membranes, axon and medullary sheath of nerve cells and hormones of several glands like ovary and adrenal cortex. Vitamin D is formed from dehydrocholesterol present in $m e d a$, by irradiation from ultraviolet rays. Vitamin D is required for the absorption of calcium and phosphate through the intestine and thus responsible for the formation of bones. This may be the reason that asthi dhatu is kept after meda dhatu. Meda, specially deposited in belly protects the internal organs from jerks and low temperature. The maintenance of temperature by it maintains the digestive process in optimum level. In chapter 7, Sharirasankhya adhyaya of sharira sthana, Acharya Charak states that the amount of meda in body is two anjali ${ }^{11}$. This indicates that the individual norms of meda and other dhatus should be different since the volume of anjali of each individual is different. Meda is non-identical from vasa since meda is a dhatu that bears the body and vasa is an updhatu and that part of the sneha of the body, which is not required for immediate energy production and hence it is stored in the body.

Medasara Purush Examination of sara is done to determine the strength of a person ${ }^{12}$. The features of 
medasara purush, according to Acharya Charak as explained in Rogabhishagjitiya adhyaya, chapter 8 in vimanasthana, is that the person's complexion, voice, eyes, hair, body hair, nails, teeth, lips, urine and stool are snigdha. The person is hedonistic, generous, fragile and helpful $^{13}$. Sushruta in Aaturopakramaniya adhyaya of sutra sthana says that the medasara purush has snigdha urine, sweat and voice. He has a large body and unable to perform hard work ${ }^{14}$. Researchers may look forward to find out that range of BMI in an obese person in which these features appear in body which will help in a more accurate classification of classes of obesity.

\section{Meda dhatu kshaya}

Not only an increase in the amount of meda dhatu is undesirable but a check must also be kept on the kshaya of meda dhatu. The meda dhatu kshaya can be determined by the signs and symptoms illustrated in ayurvedic literatures by various ancient scholars. The depletion of meda dhatu has following features according to Acharya Charak as mentioned in Kriyantashirashiya adhyaya, chapter 17 of sutrasthana - feeling of pain like breaking of joints of bone, lack of luster of eyes and decrease in waist circumference ${ }^{15}$. Acharya Sushruta has a bit different view in chapter 15, Doshadhatumalakshayavridhivigyaniya adhyaya of sutrasthana, like splenomegaly, numbness in joints of bone, dryness and wish for snigdha food ${ }^{16}$. In Doshadivigyaniyam adhyaya of sutrasthana, Acharya Vagbhatta says the similar features as above like decrease in waist circumference, splenomegaly and thin body ${ }^{17}$. Acharya Charak, in Ashthoninditiya adhyaya, chapter 21 in sutrasthana states that krishanga person have dry buttocks, abdomen and neck. Net of veins all over his over body. It seems that he has only skin and bone left in his body and bony joints are large ${ }^{18}$. According to Acharya Charak, as illustrated in Ashthoninditiya adhyaya, chapter 21 in sutrasthana, he is not able to tolerate exercise, heavy diet, hunger, thirst, medicine, very cold and very hot aahara and vihara and intercourse. Also he suffers from splenomegaly, kasa, kshaya, shwasa, gulma, arsha, udargata roga and grahanigata roga ${ }^{19}$. Acharya Sushruta in chapter 15, Doshadhatumalakshayavridhivigyaniya adhyaya of sutrasthana says that such greatly emaciated person becomes incapable of tolerating hunger, thirst, cold, breeze, rain, carrying heavy loads, gets affected generally from vata aggravation and poor in life activities, gets affected quickly by dyspnoea, cough, consumption, enlargement of spleen, weakness of digestive power, abdominal tumor bleeding disease and such other diseases and dies; all his diseases will be severe because of his poor strength ${ }^{20}$.

\section{Meda dhatu vridhi and its consequences}

The appropriate management of obesity is possible only when a vaidya understands the signs of medo dhatu vriddhi at an early stage. The signs of sthaulya were very well explained in ayurvedic literatures and are as follows Acharya Sushruta in chapter 15, Doshadhatumalakshayavridhivigyaniya adhyaya of sutrasthana says that if there is an increase in the normal value of meda dhatu, the features are - the snigdhata of the body increases, deposition of fat occurs, especially in abdomen and sides of the back, kasa, shwasa and foul smell $^{21}$. In Ashthoninditiya adhyaya, chapter 21 in sutrasthana, Acharya Charak stated the features of obese persons - the vata-pitta roga due to increased meda dhatu decrease the life span of the person. Due to increase in mansa and meda, the buttocks, abdomen and breast shake while walking. There is decreased rate of development of body and lack of activeness ${ }^{22}$. Yogaratnakara too explains this stage of morbid obesity and says that due to excessive increase in medas and mansa (fat and muscular tissue) the person's buttocks, belly and breasts becomes pendulous and his vigour is (severely) depleted. Such persons are called severely obes $^{23}$. The features stated by Acharya SusHruta in chapter 15, Doshadhatumalakshayavridhivigyaniya adhyaya of sutrasthana are a bit different. He stated that due to soft nature of meda, there occurs weakness. Due to the obstruction of path of shukra by kapha and meda, the person has decreased libido. Due to obstruction of paths of all dhatus by meda, there is decreased formation of dhatus, due to which, the person becomes weak. Person suffers from prameha pidika, fever, abscess and other vatavikaras and finally dies ${ }^{24}$. In Yogaratnakara, the short (repeated) breathing, thirst, delusion, sleepiness, sudden obstruction to breathe, laxity of the body, (excessive) hunger, sweating, foul odour of the body, decreased vitality and sexual power are the features of obesity. Generally fat is accumulated in the abdomen and bones of all the human beings that is why mostly obese person's belly is enlarged. The channels being blocked by the medas, vata become more active specially in the abdomen, excites digestive fire and desiccates the food (accelerates digestive process thus the juices of the ingested food are absorbed fast) so the indigested food is digested fast and the person desires to have food again thus due to eating (frequently) various serious complications may develop in the course of time. These two, the digestive fire and the vata, are the main complicating factors and these two together burns the obese person as wild fire burns the forest. If the fat increases excessively than Yogaratnakara considers it a bad prognosis and alarms that vata etc in this case may cause very serious diseases which may lead to an early death $^{25}$. The pathogenesis of obesity has well been explained in Madhava Nidana which says that due to lack of physical activities, due to day sleep and consumption of kapha aggravating diet, the madhur anna rasa, being snigdha in nature, produces meda. Due to obstruction of the srotas by meda, the other dhatus do not get nourished, and it's only meda whose quantity goes on increasing. This restricts most of the activities of the person. Other symptoms faced by him are breathlessness even on slight exertion, thirst, unknowlageableness, excess sleep, sudden obstructions in respiration, laxity in body, excess hunger, sweat and body odour. His life span and libido declines. Meda accumulates in small joints and belly of the person leading to enlarged belly. The meda aavrit vayu circulates in the gastrointestinal tract and ablaze the digestive fire. This digests the food very soon and exaggerates hunger. If the person is not given the food at this moment, then this produces severe complications. Vayu and agni are mainly responsible for these complications $^{26}$. Obesity increases the risks of hypertension, non-insulin dependent diabetes mellitus, gall bladder disease, heart diseases etc. In AsthonindItiya adhyaya, obesity is one of the eight undesirable constitutions $^{27}$. Here undesirable denotes that extra 
healthcare efforts are required for these persons. In today's generation too, an obese person is considered unattractive and a lean body is considered as a mark of affluence, beauty and health. Following eight doshas in obese persons are stated by Charak in Ashthoninditya adhyaya, chapter 21 in sutrasthana, denoting that obese persons have following health issues - short life span, lack of activeness, difficulty in intercourse ${ }^{\#}$, weakness, foul smell from body, excessive sweating, excessive hunger and thirst ${ }^{28}$.

\# Sexual desire diminishes in an obese person and an obese woman is prone to develop menstrual abnormalities. A twenty pound increase in basal metabolic index may increase chances of infertility by $10 \%^{29}$

The signs and symptoms illustrated by ancient scholars clearly help in estimation of obesity. To make this estimation more clear, various other parameters that are common in practice are -

Diagnosis of Obesity based on BMI: Dietary imbalance and over nutrition may lead to obesity. Obesity is defined as an excess of adipose tissue that imparts health risk; a body weight of $20 \%$ excess over ideal weight for age, sex and height is considered a health risk. A person having approximately $10 \%$ more weight than expected is labeled as overweight and a person having $20 \%$ more weight than expected may be called an obese person. The most widely used method to gauge obesity is body mass index (BMI) which is equal to weight in $\mathrm{kg} / \mathrm{height}$ in $\mathrm{m}^{2}$. The person having BMI in range of 25.0 to 29.9 come under the class 1 obesity. (Ref.- API book of Medicine, Volume 2, $9^{\text {th }}$ edition).

Percent body fat: The normal body fat in females is 18 $22 \%$, which may rise up to $33 \%$ in cases of obesity.

Skin fold measurements: It is measured at following four different places with the help of calipers-

a. Biceps- belly of biceps is measured by straightening the arm.

b. Triceps

c. Suprailiac- measured 1 inch above the hip joint.

d. Subscapular- measuring the back just below the scapula.

All four above values are added and its mean is calculated whose normal value can be evaluated from standard charts.

Broca's index: Expected weight of body must beStandard weight in $\mathrm{kg}=$ Height $($ in $\mathrm{cm})-100$

Pondral index: Height in inches / Under root of weight in pounds

Corpulence index: Actual weight / Desirable weight It should be less than 1.2.

Weight and hip ratio: It should be less than 0.85 .

Derangement of lipid profile: Derangement of lipid profile is a disorder of lipid metabolism, which can include overproduction or deficiency of lipoproteins or both. The disorder can manifest as an elevation of plasma cholesterol, triglycerides, or both, or a low high density lipoprotein level or all three together.
The normal ranges of lipid profile are - (Ref. -Textbook of Pathology, Harsh Mohan, $7^{\text {th }}$ edition, Pg- 917) -

Table: 1: Normal Range of Lipid Profile

\begin{tabular}{|c|c|c|}
\hline Component & Conventional & SI Units \\
\hline \multicolumn{3}{|c|}{ Serum Cholesterol } \\
\hline $\begin{array}{l}\text { Total Desirable } \\
\text { For Adults }\end{array}$ & $<200 \mathrm{Mg} / \mathrm{Dl}$ & $<5.17 \mathrm{Mmol} / \mathrm{L}$ \\
\hline Borderline High & $200-239 \mathrm{Mg} / \mathrm{Dl}$ & 5.17-6.18 Mmol/L \\
\hline $\begin{array}{l}\text { High } \\
\text { Undesirable }\end{array}$ & $\begin{array}{l}>\mathrm{Or}=240 \\
\mathrm{Mg} / \mathrm{Dl}\end{array}$ & $>6.18 \mathrm{Mmol} / \mathrm{L}$ \\
\hline \multicolumn{3}{|c|}{ Serum LDL-Cholesterol } \\
\hline Desirable Range & $\begin{array}{l}100-130 \\
\mathrm{Mg} / \mathrm{Dl}\end{array}$ & $<3.34 \mathrm{Mmol} / \mathrm{L}$ \\
\hline Borderline High & $130-159 \mathrm{Mg} / \mathrm{Dl}$ & 3.34-4.11 Mmol/L \\
\hline $\begin{array}{l}\text { High } \\
\text { Undesirable }\end{array}$ & $\begin{array}{l}>\mathrm{Or}=160 \\
\mathrm{Mg} / \mathrm{Dl}\end{array}$ & $>4.11 \mathrm{Mmol} / \mathrm{L}$ \\
\hline \multicolumn{3}{|c|}{ Serum HDL-Cholesterol } \\
\hline $\begin{array}{l}\text { Protective } \\
\text { Range }\end{array}$ & $>60 \mathrm{Mg} / \mathrm{Dl}$ & $>1.55 \mathrm{Mmol} / \mathrm{L}$ \\
\hline Low & $<40 \mathrm{Mg} / \mathrm{Dl}$ & $<1.03 \mathrm{Mmol} / \mathrm{L}$ \\
\hline Triglycerides & $<160 \mathrm{Mg} / \mathrm{Dl}$ & $<2.26 \mathrm{Mmol} / \mathrm{L}$ \\
\hline
\end{tabular}

Causes of obesity:

The number of fat cells remains the same until death. Their number is more in obese person than a lean person. Once an obese person becomes thin, than the number of fat cells remains the same and they just become empty. These empty fat cells create an urge to the obese person to eat more so as to fill these fat cells. Repeated overeating beyond satiety for a long duration results in setting a stage when the person do not receives satisfaction in normal amount of food resulting in overeating, and hence obesity. A home where the dinner table is always laden with eatables may also influence obesity. Thus home environment matters a lot. For a depressed and socially isolated person, food may act like a sedative and soon he becomes a prey to obesity. A decrease in BMR may result in increase in weight. This may happen due to many reasons such as hormonal imbalances or lack of exercises.

\section{Management of Obesity as mentioned in Ayurveda}

As quoted by Charak in Asthoninditiya adhyaya, exceedingly corpulent as well as exceedingly emaciated persons suffer from the same diseases or the other all the time; they are to be treated by slimming and nourishing therapies respectively. Of the two, emaciation is less harmful than corpulence even though both of them are equally in need of treatment. When subjected to diseases, the volume of suffering in the case of corpulent persons is far greater than in emaciated ones. The main difficulty with the corpulent persons is that if they are given nourishing treatment, they will grow more corpulent, they cannot even stand slimming therapy because of their strong digestive power. ${ }^{30}$ The dravyas that cause emaciation and brings lightness to the body are known as langhan dravyas. The characteristic features of langhana dravyas have been mentioned by Charak in Langhanabringhaniya adhyaya of sutrasthana as light, hot, sharp, non-slimmy, rough, subtle, dry, fluid and hard. ${ }^{31}$ Charak mentioned ten weight reducing drugs or 
revulsives in Shadavirechanashatashritiyaadhyaya of sutra sthana as following: musta, kustha, haridra, daruharidra, vacha, ativisha, katurohini, chitrak, chirbilwa and hemwati under the class of lekhaniya mahakashaya. ${ }^{32}$ Various drugs indicated in Yogaratnakara for obesity are Trayosanadya loha ${ }^{33}$, Navaka guggulu ${ }^{34}$, Triphaladya taila ${ }^{35}$, Mahasugandhi taila $^{36}$, Rasbhasma yoga ${ }^{37}$, Trimurti rasa ${ }^{38}$, Vadavagni rasa $^{39}$, etc. For the cure of foul odour of body in obese persons, various applications and unguents, with main compositions of cuttlefish bone, vasa, bilva, babbula leaves, jambu leaves, etc are also mentioned in Yogaratnakara $^{40}$. The drugs mentioned in Bharat Bhaishajya Ratnakar by Shree Naginadas Chaganalal Shah Rasvaidyain are Bilwadi Kwath, Phalatrikadichurnam, Dashang guggulu and Babooladi yoga ( for excess perspiration). Regular practices of pranayam like Kapalbhati and Bhasrika may increase lung capacity and help burning fats. Specific yoga practices like Paschimottasana and Gomukhasana for pancreas and Halasana and Shirsana for thyroid are helpful in stimulating these glands by influencing their blood supply and ultimately have an indirect impact in regulating the BMI of a person. Most of the health problems develop due to the faulty eating habits and regimen. The diet and regimen which is beneficial to body and calms the mind is known as pathya. Charak mentioned following pathya aahar and vihar in Asthonindatiya adhyaya.

Table: 2: Pathya and Apathya Aahar beneficial in Obesity

\begin{tabular}{|c|c|}
\hline Pathya Aahaar & Pathya Vihar \\
\hline $\begin{array}{l}\text { Prashatika (Setaria italic Beauv.), } \\
\text { Priyangu (Aglaia roxburghiana } \\
\text { Mig.), Shyamaka (Echinochloa } \\
\text { frumentaced Linn.), Yavaka (small } \\
\text { variety of Hordeum vulgare Pars.), } \\
\text { Yava (Hordeum vulgare Linn.), } \\
\text { Joorna (Sorghum vulgare Pars.), } \\
\text { Kodrava (Paspalum scrobiculatum } \\
\text { Linn.), Moonga (Phaseolus mungo } \\
\text { Linn.), Kulatha (Dolichos biftorus } \\
\text { Linn.), Chakramudgaka, Seeds of } \\
\text { Aadhaki (Cajanus cajan Millsp.), } \\
\text { Patola (Trichosanlhes cucumerina } \\
\text { Linn.), Aamlaki (Emblica } \\
\text { officinalis Gaertn.) } \\
\text { Honey syrup and alcoholic } \\
\text { preparations that help to reduce } \\
\text { fat, muscle and kapha may be used } \\
\text { as anupan. }\end{array}$ & $\begin{array}{l}\text { Vigil, Sexual act, Physical } \\
\text { and mental exercises }\end{array}$ \\
\hline
\end{tabular}

\section{REFERENCES}

1. https://en.m.wikipedia.org/wiki/Abnormal_basal_metabolic_ra te

2. www.who.int/news-room/fact-sheets/detail/obesity-andoverweight

3. Katyayan A, Vinodini Hindi Commentary, Bhel Samhita, Sutra Sthana - 11/10, Edition - 2009, Chaukhamba Surabharati Prakashan, Varanasi, Page no. 67.

4. Shastri S N, Vidyotini Hindi Commentary, Charak Samhita vol.-1, Sharir Sthana - 7/15, Edition - 2008, Chaukhamba Sanskrit Sansthan, Varanasi, Page no. 815.

5. Shastri S N, Vidyotini Hindi Commentary, Charak Samhita vol.-2, Chikitsa Sthana - 15/16, Edition - 2008, Chaukhamba Sanskrit Sansthan, Varanasi, Page no. 380.

\section{DISCUSSION}

The origin and depletion of the seven dhatus are interconnected. To avoid the condition of sthaulya, it is therefore mandatory to keep all the dhatus in optimum quantity by taking adequate diet, and not just concentrating on the constituents affecting the quantity of meda dhatu. The children of obese parents are more prone to develop overweight in future. They must therefore be frequently monitored for the estimation of obesity and a special care to be taken while preparing their diet chart. Yoga and pranayam keep a control on obesity by burning excess fat, improving circulation, promoting sweating, clearing obstruction of many channels, affecting endocrinal secretions and increasing lung capacity. Introduction of yoga, pathya aahar-vihar, langhan dravyas and other dravyas mentioned above should be done keeping the prakriti of the person and $y u k t i$ of administration into consideration. Accepting a new schedule and rejecting a non-essential ones must be done in padanshik manner. One should be conscious of not developing the risk factors of obesity like diabetes, hypertension, etc including depression. Obesity being a lifestyle disorder can be easily conquered if fought with strong determination and patience.

\section{CONCLUSION}

By analyzing the extent of importance given to obesity by ancient scholars, we may understand the need to analyze the causes, pathology and management of this disorder. An obese person not only faces a difficulty in performing the daily routine work but also becomes a subject of taunts and teases and faces isolation from the society. Intake of excessive unhealthy and junk food, lack of exercise and genetic susceptibility are the prime causes for this curse which further deteriorates the condition of the person by giving rise to other complications. As mentioned in ayurveda, the earlier we take the treatment of this disease into consideration, the easier it becomes to treat it, avoiding any chances of the complications. Nidan pariwarjan is a way to stay away from obesity simply by keeping oneself away from the etiological factors of obesity. One should keep such vihara factors, such as anger, depression at an arm's length. Following the pathya and apathya mentioned in ayurveda is a must even if a person takes medications for minimizing the obesity level. Simple living and healthy eating may act as a prophylactic management.

6. Shastri A D, Ayurveda Tattva Sandipika Hindi Commentary, Sushrut Samhita vol. - 1, Sharir Sthana - 4/12, Edition 2011, Chaukhamba Sanskrit Sansthan, Varanasi, Page no. 39.

7. Shastri A D, Ayurveda Tattva Sandipika Hindi Commentary, Sushrut Samhita vol. - 1, Sharir Sthana - 4/13, Edition 2011, Chaukhamba Sanskrit Sansthan, Varanasi, Page no. 39.

8. Kumari A, Tewari P. English Commentary, Yogaratnakara part - 2, 40/1, Edition - 2010, Chaukhamba Visvabharati, Varanasi, Page no. 771.

9. Kumari A, Tewari P. English Commentary, Yogaratnakara part - 2, 40/2, Edition - 2010, Chaukhamba Visvabharati, Varanasi, Page no. 771 .

10. Shastri A D, Ayurveda Tattva Sandipika Hindi Commentary, Sushrut Samhita vol. - 1, Sutra Sthana - 15/7, Edition - 2011, Chaukhamba Sanskrit Sansthan, Varanasi, Page no. 75. 
11. Shastri S N, Vidyotini Hindi Commentary, Charak Samhita vol.-1, Sharir Sthana - 7/15, Edition - 2008, Chaukhamba Sanskrit Sansthan, Varanasi, Page no. 815.

12. Shastri S N, Vidyotini Hindi Commentary, Charak Samhita vol.-1, Viman Sthana - 8/114, Edition - 2008, Chaukhamba Sanskrit Sansthan, Varanasi, Page no. 778.

13. Shastri S N, Vidyotini Hindi Commentary, Charak Samhita vol.-1, Viman Sthana - 8/106, Edition - 2008, Chaukhamba Sanskrit Sansthan, Varanasi, Page no. 776.

14. Shastri A D, Ayurveda Tattva Sandipika Hindi Commentary, Sushrut Samhita vol. - 1, Sutra Sthana - 35/18, Edition 2011, Chaukhamba Sanskrit Sansthan, Varanasi, Page no. 170.

15. Shastri S N, Vidyotini Hindi Commentary, Charak Samhita vol.-1, Sutra Sthana - 17/66, Edition - 2008, Chaukhamba Sanskrit Sansthan, Varanasi, Page no. 348.

16. Shastri A D, Ayurveda Tattva Sandipika Hindi Commentary, Sushrut Samhita vol. - 1, Sutra Sthana - 15/13, Edition 2011, Chaukhamba Sanskrit Sansthan, Varanasi, Page no. 76.

17. Gupt A D, Vidyotini Hindi Commentary, Astang Hridaya, Sutra Sthana - 11/18, Edition - 2009, Chaukhamba Prakashan, Varanasi, Page no. 116.

18. Shastri S N, Vidyotini Hindi Commentary, Charak Samhita vol.-1, Sutra Sthana - 21/15, Edition - 2008, Chaukhamba Sanskrit Sansthan, Varanasi, Page no. 412.

19. Shastri S N, Vidyotini Hindi Commentary, Charak Samhita vol.-1, Sutra Sthana - 21/14, Edition - 2008, Chaukhamba Sanskrit Sansthan, Varanasi, Page no. 412.

20. Shastri A D, Ayurveda Tattva Sandipika Hindi Commentary, Sushrut Samhita vol. - 1, Sutra Sthana - 15/39, Edition 2011, Chaukhamba Sanskrit Sansthan, Varanasi, Page no. 82.

21. Shastri A D, Ayurveda Tattva Sandipika Hindi Commentary, Sushrut Samhita vol. - 1, Sutra Sthana - 15/19, Edition 2011, Chaukhamba Sanskrit Sansthan, Varanasi, Page no. 78.

22. Shastri S N, Vidyotini Hindi Commentary, Charak Samhita vol.-1, Sutra Sthana - 21/8-9, Edition - 2008, Chaukhamba Sanskrit Sansthan, Varanasi, Page no. 411.

23. Kumari A, Tewari P. English Commentary, Yogaratnakara part - 2, 40/9-10, Edition - 2010, Chaukhamba Visvabharati, Varanasi, Page no. 772.

24. Shastri A D, Ayurveda Tattva Sandipika Hindi Commentary, Sushrut Samhita vol. - 1, Sutra Sthana - 15/37, Edition 2011, Chaukhamba Sanskrit Sansthan, Varanasi, Page no. 81.

25. Kumari A, Tewari P. English Commentary, Yogaratnakara part - 2, 40/3-8, Edition - 2010, Chaukhamba Visvabharati, Varanasi, Page no. 771.
26. Shastri B S, Manorama Hindi Commentary, Madhav Nidan, 34/1-8, Edition - 2006, Chaukhamba Sanskrit Sansthan, Varanasi, Page no. 217.

27. Shastri S N, Vidyotini Hindi Commentary, Charak Samhita vol.-1, Sutra Sthana - 21/3, Edition - 2008, Chaukhamba Sanskrit Sansthan, Varanasi, Page no. 407.

28. Shastri S N, Vidyotini Hindi Commentary, Charak Samhita vol.-1, Sutra Sthana - 21/4, Edition - 2008, Chaukhamba Sanskrit Sansthan, Varanasi, Page no. 409.

29. https://www.google.co.in/amp/s/blog.episona.com/7questions-about-weight-and-male-infertility\%fhs_amp=true

30. Shastri S N, Vidyotini Hindi Commentary, Charak Samhita vol.-1, Sutra Sthana - 21/17, Edition - 2008, Chaukhamba Sanskrit Sansthan, Varanasi, Page no. 413.

31. Shastri S N, Vidyotini Hindi Commentary, Charak Samhita vol.-1, Sutra Sthana - 22/12, Edition - 2008, Chaukhamba Sanskrit Sansthan, Varanasi, Page no. 425.

32. Shastri S N, Vidyotini Hindi Commentary, Charak Samhita vol.-1, Sutra Sthana - 4/8-3, Edition - 2008, Chaukhamba Sanskrit Sansthan, Varanasi, Page no. 72.

33. Kumari A, Tewari P. English Commentary, Yogaratnakara part - 2, 40/18-20, Edition - 2010, Chaukhamba Visvabharati, Varanasi, Page no. 773.

34. Kumari A, Tewari P. English Commentary, Yogaratnakara part - 2, 40/21, Edition - 2010, Chaukhamba Visvabharati, Varanasi, Page no. 773.

35. Kumari A, Tewari P. English Commentary, Yogaratnakara part - 2, 40/30-32, Edition - 2010, Chaukhamba Visvabharati, Varanasi, Page no. 774.

36. Kumari A, Tewari P. English Commentary, Yogaratnakara part - 2, 40/33-38, Edition - 2010, Chaukhamba Visvabharati, Varanasi, Page no. 775.

37. Kumari A, Tewari P. English Commentary, Yogaratnakara part - 2, 40/39, Edition - 2010, Chaukhamba Visvabharati, Varanasi, Page no. 775.

38. Kumari A, Tewari P. English Commentary, Yogaratnakara part - 2, 40/40-42, Edition - 2010, Chaukhamba Visvabharati, Varanasi, Page no. 775.

39. Kumari A, Tewari P. English Commentary, Yogaratnakara part - 2, 40/43-44, Edition - 2010, Chaukhamba Visvabharati, Varanasi, Page no. 776.

40. Kumari A, Tewari P. English Commentary, Yogaratnakara part - 2, 40/22-28, Edition - 2010, Chaukhamba Visvabharati, Varanasi, Page no. 773. 